\title{
Increased concentration of serum TNF alpha and its correlations with arterial blood pressure and indices of renal damage in dogs infected with Babesia canis
}

\author{
Wojciech Zygner • Olga Gójska-Zygner • Piotr Bąska • \\ Ewa Dlugosz
}

Received: 2 January 2014 / Accepted: 28 January 2014 / Published online: 20 February 2014

(C) The Author(s) 2014. This article is published with open access at Springerlink.com

\begin{abstract}
Canine babesiosis is a tick-borne disease caused by parasites of the genus Babesia. Tumour necrosis factor alpha $(\mathrm{TNF}-\alpha)$ is a cytokine that plays a role in the pathogenesis of canine babesiosis. In this study, the authors determined the concentration of serum TNF- $\alpha$ in 11 dogs infected with Babesia canis and calculated Spearman's rank correlations between the concentration of TNF- $\alpha$ and blood pressure, and between TNF- $\alpha$ and indices of renal damage such as: fractional excretion of sodium $\left(\mathrm{FE}\left(\mathrm{Na}^{+}\right)\right)$, urinary creatinine to serum creatinine ratio $(\mathrm{UCr} / \mathrm{SCr})$, renal failure index $(\mathrm{RFI})$, urine specific gravity (USG) and urinary protein to urinary creatinine ratio (UPC). The results demonstrated statistically significant strong negative correlations between TNF- $\alpha$ and systolic arterial pressure $(r=-0.7246)$, diastolic arterial pressure $(r=-0.6642)$ and mean arterial pressure $(r=-0.7151)$. Serum TNF- $\alpha$ concentration was also statistically significantly correlated with $\mathrm{FE}\left(\mathrm{Na}^{+}\right)(r=0.7056), \mathrm{UCr} / \mathrm{SCr}(r=$ $-0.8199)$, USG $(r=-0.8075)$ and duration of the disease $(r=0.6767)$. The results of this study show there is an increase of serum TNF- $\alpha$ concentration during canine babesiosis, and the increased TNF- $\alpha$ concentration has an influence on the development of hypotension and renal failure in canine babesiosis. This probably results from the fact that
\end{abstract}

\footnotetext{
W. Zygner $(\bowtie) \cdot$ E. Długosz

Division of Parasitology, Department of Preclinical Sciences, Faculty

of Veterinary Medicine, Warsaw University of Life Sciences,

Ciszewskiego 8, 02-786 Warsaw, Poland

e-mail: wojciechzygner@yahoo.pl

O. Gójska-Zygner

Multiwet Small Animal Health Clinic, Gagarina 5, 00-753 Warsaw, Poland

P. Bąska

Division of Pharmacology and Toxicology, Department of Preclinical Sciences, Faculty of Veterinary Medicine, Warsaw University of Life Sciences, Ciszewskiego 8, 02-786 Warsaw, Poland
}

TNF- $\alpha$ is involved in the production of nitric oxide and induction of vasodilation and hypotension, which may cause renal ischaemia and hypoxia, and finally acute tubular necrosis and renal failure.

\section{Introduction}

Canine babesiosis is a protozoan disease caused by the parasites of the genus Babesia (Matijatko et al. 2012). In Europe, canine babesiosis can be caused by infection with species such as Babesia canis, Babesia vogeli and Babesia gibsoni. Moreover, two species, Babesia felis-like and Babesia microti-like (now considered as Theileria annae), were detected in Germany in dogs imported from Romania, and in Spain, respectively (Hamel et al. 2012; Matijatko et al. 2012). Among these Babesia species, only B. canis has been detected in Poland (Adaszek and Winiarczyk 2011).

Tumour necrosis factor alpha (TNF- $\alpha$ ) is a proinflammatory cytokine that plays a significant role in the pathogenesis of babesiosis and malaria, and influences the severity of these diseases (Hemmer et al. 2000; Krause et al. 2007). Complications of canine babesiosis, such as multiple organ dysfunction syndrome and hypotension may result from the parasite, the host or parasite-host interactions (Matijatko et al. 2012). It is probable that TNF- $\alpha$ is involved in the development of hypotension, renal dysfunction and septic shock in canine babesiosis (Matijatko et al. 2009).

Parameters such as fractional excretion of sodium $\left(\mathrm{FE}\left(\mathrm{Na}^{+}\right)\right)$, urinary creatinine to serum creatinine ratio $(\mathrm{UCr} / \mathrm{SCr})$, renal failure index (RFI), urine specific gravity (USG) and urinary protein to urinary creatinine ratio (UPC) are useful in the differentiation between prerenal and renal azotaemia in azotaemic dogs (Stockham and Scott 2008; Waldrop 2008; Lefebvre 2011).

The purpose of this study was to determine correlations between serum TNF- $\alpha$ concentration and indices 
of azotaemia (serum urea and creatinine concentration), renal failure indices and blood pressures in dogs infected with B. canis.

\section{Materials and methods}

Blood, serum and urine samples were collected from 11 dogs of various breeds (Table 1) infected with $B$. canis prior to treatment. Diagnosis of infection with $B$. canis was based on the results of a blood smear examination (Fig. 1) and confirmed by the PCR method described in previous work (Zygner et al. 2012a). Eight clinically healthy dogs were used as a control group. Clinical examination, including blood pressure measurement, was performed during the first visit to the clinic, before sample collection and treatment. Systolic arterial pressure (SAP), diastolic arterial pressure (DAP), mean arterial pressure (MAP) and pulse pressure (PP) were determined using the non-invasive oscillometric technique
(Cardell veterinary monitor 9405, Midmark, USA). The concentration of TNF- $\alpha$ in serum samples was determined using an ELISA kit (Quantikine ELISA Canine TNF- $\alpha$, R\&D Systems) and read by an ELISA reader at wavelength $450 \mathrm{~nm}$ (MRX Microplate Reader, Dynatech Laboratories) using the program Revelation (version 4.25). Creatinine concentrations (in serum and urine), serum urea concentration and urinary protein concentration were determined by a clinical chemistry analyser (XL 640, Erba Mannheim, Germany). Serum and urinary sodium concentrations were also determined using a clinical chemistry analyser (MEDICA Easy Electrolytes, the Netherlands). Prior to determination of the sodium concentration, urine samples were centrifuged (2,000 rpm, $5 \mathrm{~min})$, then diluted tenfold in deionized water. Urine specific gravity (USG) was determined using a veterinary refractometer (Reichert VET 360, Reichert, USA). The obtained results allowed calculation of indices of renal damage such as $\mathrm{FE}\left(\mathrm{Na}^{+}\right), \mathrm{UCr} / \mathrm{SCr}$, RFI and UPC. The $\mathrm{FE}\left(\mathrm{Na}^{+}\right)$ and RFI were calculated using the following formulas:

Table 1 Individual values of serum TNF- $\alpha$ concentrations, blood pressure and renal indices, and clinical signs in 11 dogs with babesiosis

\begin{tabular}{|c|c|c|c|c|c|c|c|c|c|c|c|}
\hline Parameter & I & II & III & IV & $\mathrm{V}$ & VI & VII & VIII & IX & $\mathrm{X}$ & $\mathrm{XI}$ \\
\hline TNF- $\alpha$ & 20.1 & 18.7 & 0 & 14.7 & 0 & 0 & 27.8 & 0 & 26.5 & 15.5 & 0 \\
\hline SAP & 83 & 87 & 120 & 118 & 125 & 121 & 117 & 115 & 70 & 81 & 127 \\
\hline DAP & 55 & 44 & 90 & 72 & 87 & 72 & 62 & 60 & 52 & 45 & 86 \\
\hline MAP & 74 & 73 & 110 & 103 & 112 & 105 & 99 & 97 & 64 & 69 & 113 \\
\hline PP & 28 & 43 & 30 & 46 & 38 & 49 & 55 & 55 & 18 & 36 & 41 \\
\hline $\mathrm{SCr}$ & 4.6 & 5.1 & 1.1 & 1 & 1 & 1.2 & 1.7 & 1 & 2.8 & 3.3 & 1 \\
\hline SUr & 462 & 264 & 39 & 42 & 38 & 32 & 44 & 44 & 166 & 181 & 42 \\
\hline $\mathrm{UCr}$ & 52 & 15.6 & 161 & 40 & 128 & 281 & 60 & 528 & 75 & 100 & 169 \\
\hline $\mathrm{UNa}$ & 151 & 168 & 84 & 97 & 65 & 57 & 19 & 108 & 39 & 12 & 71 \\
\hline $\mathrm{SNa}$ & 141 & 137 & 140 & 137 & 139 & 142 & 146 & 145 & 151 & 146 & 144 \\
\hline $\mathrm{FE}\left(\mathrm{Na}^{+}\right)$ & 9.47 & 40.09 & 0.41 & 1.77 & 0.36 & 0.17 & 3.69 & 0.14 & 0.96 & 0.27 & 0.29 \\
\hline $\mathrm{UCr} / \mathrm{SCr}$ & 11.3 & 3.1 & 146.4 & 40 & 128 & 234.2 & 35.3 & 528 & 26.8 & 30.3 & 169 \\
\hline RFI & 13.3 & 54.9 & 0.6 & 2.4 & 0.5 & 0.2 & 0.5 & 0.2 & 1.5 & 0.4 & 1.7 \\
\hline USG & 1.013 & 1.014 & 1.039 & 1.060 & 1.045 & 1.042 & 1.005 & 1.050 & 1.013 & 1.016 & 1.040 \\
\hline UP & 160 & 0 & 0 & 520 & 2250 & 345 & 0 & 1128 & 3235 & 820 & 0 \\
\hline UPC & 3.08 & 0 & 0 & 13 & 17.58 & 1.23 & 0 & 2.14 & 43.13 & 8.2 & 0 \\
\hline DD & 4 & 3 & 2 & 1 & 1 & 1 & 2 & 1 & 3 & 2 & 2 \\
\hline $\mathrm{CS}$ & An, Ap & $\begin{array}{c}\text { An, Ap, } \\
\text { S, F, } \\
\text { Tc, Tp }\end{array}$ & $\begin{array}{c}\text { An, Ap, } \\
\text { F, V }\end{array}$ & $\begin{array}{l}\text { DA, Ap, } \\
\text { F, Tc, } \\
\text { Tp, DBU }\end{array}$ & $\begin{array}{l}\text { An, Ap, } \\
\quad \text { F, Tc, Tp, } \\
\text { DBU }\end{array}$ & An, Ap, F & $\begin{array}{c}\text { An, Ap, } \\
\text { F, Tc, } \\
\text { Tp }\end{array}$ & DA, Ap, F & $\begin{array}{l}\text { An, Ap, } \\
\text { F, DBU }\end{array}$ & $\begin{array}{c}\text { An, Ap, } \\
\text { F, V }\end{array}$ & An, Ap \\
\hline DS & $\begin{array}{c}\mathrm{D}, \mathrm{FM} \\
10 \mathrm{y}\end{array}$ & $\begin{array}{l}\text { SBD, } \\
\text { FM, 7y }\end{array}$ & $\begin{array}{l}\mathrm{GSc}, \\
\mathrm{M}, 6 \mathrm{y}\end{array}$ & $\begin{array}{c}\text { JRT, M, } \\
3 \mathrm{y}\end{array}$ & $\begin{array}{l}\text { MBD, } \\
\text { FM, 8y }\end{array}$ & $\begin{array}{l}\text { MBD, } \\
\text { FM, 4y }\end{array}$ & $\begin{array}{l}\text { MBD, } \\
\quad \mathrm{M}, 2 \mathrm{y}\end{array}$ & $\begin{array}{c}\mathrm{H}, \mathrm{FM}, \\
6 \mathrm{y}\end{array}$ & $\begin{array}{c}\text { GSh, M, } \\
1 \mathrm{y}\end{array}$ & $\begin{array}{c}\mathrm{GR}, \mathrm{FM}, \\
11 \mathrm{y}\end{array}$ & $\begin{array}{l}\text { MBD, } \\
\text { FM, 3y }\end{array}$ \\
\hline
\end{tabular}

$I$ to $X I$ numbering of dogs, $T N F$ - $\alpha$ tumour necrosis factor (in picograms per milliliter), $S A P$ systolic arterial pressure (in millimeters of mercury), $D A P$ diastolic arterial pressure (in millimeters of mercury), $M A P$ mean arterial pressure (in millimeters of mercury), $P P$ pulse pressure (in millimeters of mercury), $S C r$ serum creatinine concentration (in milligrams per deciliter), $S U r$ serum urea concentration (in milligrams per deciliter), $U C r$ urinary creatinine concentration (in milligrams per deciliter), $U N a$ urinary sodium concentration (in milliequivalents per liter), $S N a$ serum sodium concentration (in milliequivalents per liter), $F E\left(\mathrm{Na}^{+}\right.$) fractional excretion of sodium (in percent), $U \mathrm{Cr} / \mathrm{SCr}$ urinary creatinine to serum creatinine ratio, $R F I$ renal failure index, $U S G$ urine specific gravity, $U P$ urinary protein concentration (in milligrams per deciliter), $U P C$ urinary protein to urinary creatinine ratio, $D D$ duration of the disease (in days), $C S$ clinical signs, $D S$ description of the dog (breed, sex and age in years), $A n$ anorexia, $A p$ apathy, $S$ seizures, $F$ fever, $T c$ tachycardia, $T p$ tachypnoea, $V$ vomiting, $D A$ decreased appetite, $D B U$ dark-brown urine, $F M$ female, $M$ male, $D$ Dachshund, $S B D$ St. Bernard dog, $G S c$ Giant Schnauzer, JRT Jack Russell Terrier, MBD mixed breed dog, $H$ Hovawart, GSh German Shepherd, GR Golden Retriever 


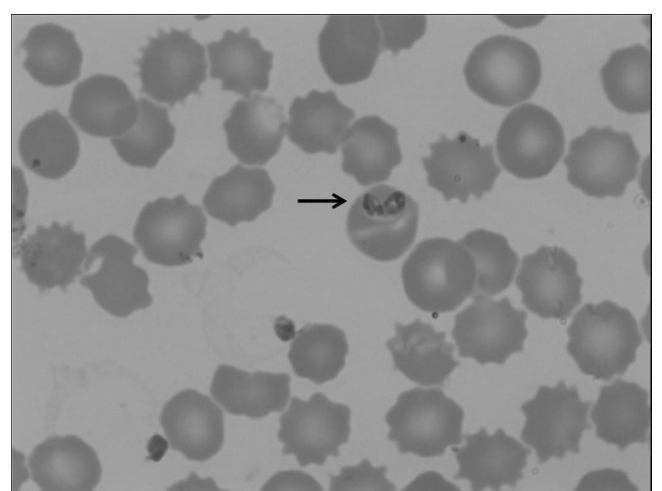

Fig. 1 Two B. canis merozoites (arrow) within red blood cell observed in blood smear (May-Grünwald-Giemsa staining)

$\mathrm{FE}\left(\mathrm{Na}^{+}\right)=\mathrm{UNa} \times \mathrm{SCr} \times 100 \% \div \mathrm{SNa} \times \mathrm{UCr}$ and $\mathrm{RFI}=\mathrm{UNa} \times$ $\mathrm{SCr} \div \mathrm{UCr}$, respectively; where $\mathrm{UNa}$ is the urinary sodium concentration, $\mathrm{SCr}$ is the serum creatinine concentration, $\mathrm{SNa}$ is the serum sodium concentration and $\mathrm{UCr}$ is the urinary creatinine concentration (Waldrop 2008). The results were analysed using the program Statistica 10 . The MannWhitney $U$ test was used to compare serum TNF- $\alpha$ concentrations between 8 healthy dogs (group A) and 11 dogs infected with B. canis (group B). Spearman's rank correlation coefficient was used to calculate correlations between serum TNF- $\alpha$ concentrations in dogs infected with $B$. canis and their blood pressures (SAP, DAP, MAP and PP), serum urea and creatinine concentrations, $\mathrm{FE}\left(\mathrm{Na}^{+}\right), \mathrm{UCr} / \mathrm{SCr}$, RFI USG, UPC and the duration of the disease before admission to the clinic. The value of $p<0.05$ was considered significant.

\section{Results}

The individual results of 11 dogs infected with $B$. canis are presented in Table 1. Apathy, anorexia and fever were the most prevalent clinical signs. Detectable concentrations of TNF- $\alpha$ were present in the serum of 6 of the 11 infected dogs. The median serum TNF- $\alpha$ concentration in these dogs amounted to $14.7 \mathrm{pg} / \mathrm{mL}$. Comparison of TNF- $\alpha$ concentrations between groups A and B showed a statistically significantly higher median in infected dogs (Fig. 2). There were statistically significant negative correlations between TNF- $\alpha$ concentration and blood pressures (SAP, DAP and MAP); however, there was no correlation between PP and TNF- $\alpha$ (Table 2). Statistically significant positive correlations were observed between TNF- $\alpha$ concentration and serum urea, serum creatinine and $\mathrm{FE}\left(\mathrm{Na}^{+}\right)$(Table 2). Statistically significant negative correlations between TNF- $\alpha$ concentrations and $\mathrm{UCr} / \mathrm{SCr}$ ratio and USG were also observed. There were no statistically significant correlations between TNF- $\alpha$ and RFI or UPC. Duration of the disease was statistically significantly correlated with serum TNF- $\alpha$ concentration (Table 2).

\section{Discussion}

This study showed increased TNF- $\alpha$ concentrations in the sera of dogs infected with $B$. canis. A similar result has been observed in dogs experimentally infected with Rangelia vitalii, which is a protozoan parasite that causes canine piroplasmosis in Brazil (Da Silva et al. 2013; Paim et al. 2013). Increase of serum TNF- $\alpha$ concentration has also been observed in human and bovine babesiosis (Shaio and Lin 1998; Kontaş and Salmanoğlu 2006).

The authors of this research detected a strong negative correlation between increased serum levels of TNF- $\alpha$ and blood pressure. This may result from the fact that TNF- $\alpha$ is involved in the production of nitric oxide and induction of vasodilation and hypotension (Jacobson et al. 2002; Chauvin et al. 2009). In a previous study, Zygner and Gójska-Zygner (Association between decreased blood pressure and azotaemia in canine babesiosis. Pol J Vet Sci, accepted for publication) showed a negative correlation between blood pressure and the concentration of blood urea and creatinine, as well as lower blood pressure in azotaemic dogs infected with $B$. canis in comparison to non-azotaemic dogs with canine babesiosis. Thus, it seems probable that the observed strong correlation in this study between serum levels of TNF- $\alpha$ and renal indices such as $\mathrm{FE}\left(\mathrm{Na}^{+}\right)$and $\mathrm{UCr} / \mathrm{SCr}$ ratio result from the influences of decreased blood pressure and/or TNF- $\alpha$ on renal failure in canine babesiosis. In previous research, Tracey et al. (1987) showed that injection of dogs with a high dose of TNF- $\alpha$ led to acute tubular necrosis. Increase of the $\mathrm{FE}\left(\mathrm{Na}^{+}\right)$and RFI and decrease of the $\mathrm{UCr} / \mathrm{SCr}$ ratio are indicative for acute tubular necrosis (Waldrop 2008); such changes have previously been observed in dogs infected with B. canis (Zygner et al. 2012b, 2013). However, in this study, the RFI was not correlated with TNF- $\alpha$. This might result from the small group of dogs examined and is an area that requires further research.

The observation in this study of a strong negative correlation between the level of serum TNF- $\alpha$ and USG may also result from an increase in the severity of renal failure, or alternatively, a change from pre-renal azotaemia (higher USG) into renal azotaemia (lower USG) with a concurrent increase of the serum TNF- $\alpha$ concentration. In this work, all azotaemic dogs had relatively low USG (1.013-1.016), but not isosthenuria. One dog had hyposthenuria (USG, <1.008), and serum levels of urea and creatinine were at the upper reference intervals in this dog; thus, it cannot be excluded that azotaemia was developing in this dog. It should also be mentioned that the USG value (decreasing) can be influenced by other factors such as cortisol or aldosterone (Watson 1998); increases in plasma cortisol concentrations have been observed in dogs with canine babesiosis caused by Babesia canis rossi (Schoeman et al. 2007). Moreover, previous work has indicated that the hyponatraemia, hypokalaemia and increased fractional excretions of sodium and potassium observed during canine babesiosis may be 
Fig. 2 Comparison of TNF- $\alpha$ concentrations between 8 healthy $\operatorname{dogs}($ group A) and $11 \operatorname{dogs}$ infected with B. canis (group B)

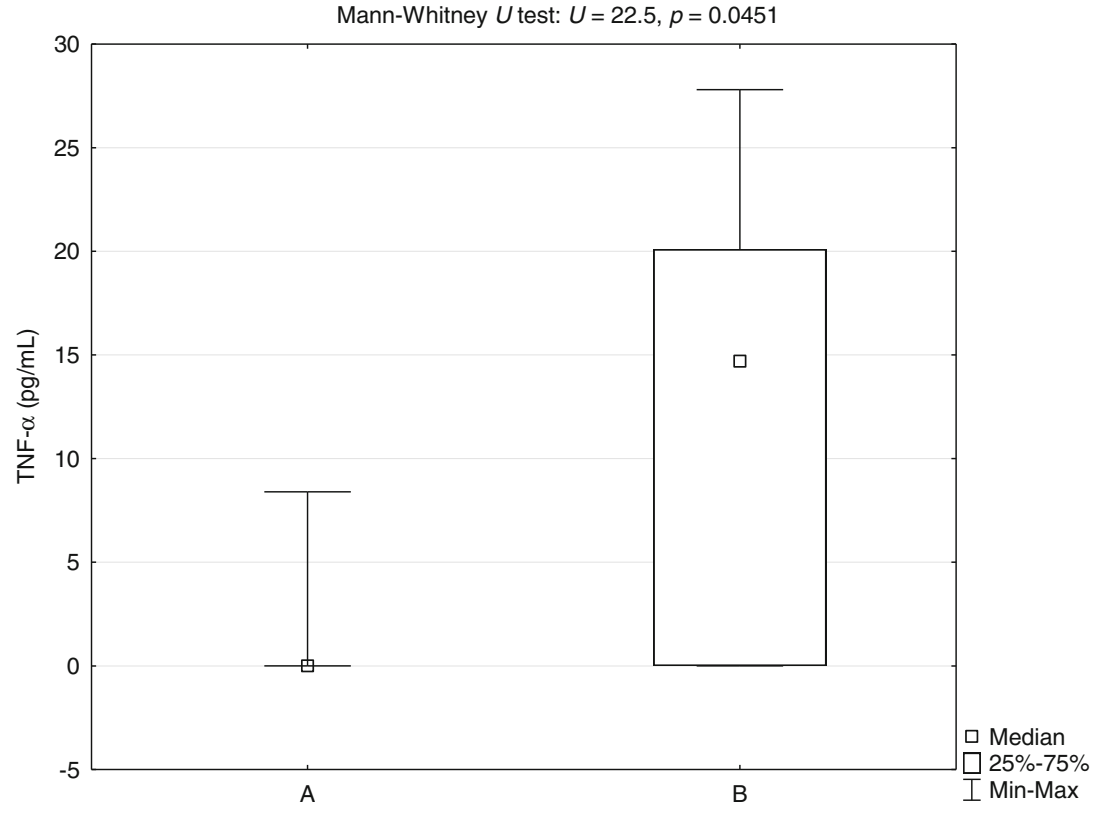

connected to an increase of aldosterone during the disease (Adaszek et al. 2012; Zygner et al. 2012a, 2012b).

There was no statistically significant correlation between the TNF- $\alpha$ concentration and UPC in this study. Lobetti and Jacobson (2001) observed a correlation between the value of UPC and severity of babesiosis caused by B. rossi. In theory, UPC is a useful tool in clinical recognition of damage of renal glomeruli when increasing above values of $0.5-1.0$ in

Table 2 Spearman's rank correlation between concentration of TNF- $\alpha$ in serum of 11 dogs infected with $B$. canis and blood pressures, serum urea, creatinine and other renal indices

\begin{tabular}{llll}
\hline Correlation & & $r$ & $p$ \\
\hline TNF- $\alpha$ & SAP & -0.7246 & $0.0116^{*}$ \\
& DAP & -0.6642 & $0.0258^{*}$ \\
MAP & -0.7151 & $0.0134^{*}$ \\
& PP & -0.1911 & 0.5841 \\
SUr & 0.7232 & $0.0119^{*}$ \\
SCr & 0.7075 & $0.0149^{*}$ \\
& FE(Na $\left.{ }^{+}\right)$ & 0.7056 & $0.0153^{*}$ \\
& UCr/SCr & -0.8199 & $0.0019^{*}$ \\
RFI & 0.3927 & 0.2322 \\
USG & -0.8075 & $0.0026^{*}$ \\
& UPC & 0.1219 & 0.7209 \\
DD & 0.6767 & $0.0222^{*}$ \\
\hline
\end{tabular}

$T N F$ - $\alpha$ tumour necrosis factor alpha, $S A P$ systolic arterial pressure, $D A P$ diastolic arterial pressure, $M A P$ mean arterial pressure, $P P$ pulse pressure, $S U r$ serum urea concentration, $S C r$ serum creatinine concentration, $\mathrm{FE}\left(\mathrm{Na}^{+}\right)$fractional excretion of sodium, $\mathrm{UCr} / \mathrm{SCr}$ urinary creatinine to serum creatinine ratio, $R F I$ renal failure index, $U S G$ urine specific gravity, $U P C$ urinary protein to urinary creatinine ratio, $D D$ duration of the disease (days), $r$ Spearman's rank correlation coefficient, $p$ a value of $p$

${ }^{\text {a }}$ Statistically significant result azotaemic dogs (Stockham and Scott 2008). However, damage of renal glomeruli, although mentioned by Wozniak et al. (1997) in experimentally infected dogs with B. gibsoni, has been rarely observed and mild in dogs with babesiosis (Irwin and Hutchinson 1991; Máthé et al. 2007). In this study, increase of UPC was observed in 7 out of 11 dogs infected with B. canis. However, in these dogs, haemoglobinuria and/or bacteriuria were detected which might influence the protein concentration in urine. The observed lack of correlation between UPC and TNF- $\alpha$ concentration in this research is in agreement (provided decreased blood pressure results from increased TNF- $\alpha$ concentration) with the results of previous work in which a lack of a correlation between UPC and decrease of blood pressure was observed (Buranakarl et al. 2007).

In this work, there were strong positive correlations between serum TNF- $\alpha$ concentration and concentrations of serum urea and creatinine, which suggested that cytokine has an influence on the development of azotaemia in canine babesiosis. Additionally, the correlation between duration of the disease and TNF- $\alpha$ concentration suggested that this cytokine is involved in the development of pre-renal azotaemia, caused by hypotension, at the beginning of the disease and further, is involved in renal azotaemia caused by renal hypoxia when the disease is progressing.

The results of this study show there is an increase in the serum TNF- $\alpha$ concentration in canine babesiosis and that the increased TNF- $\alpha$ concentration influences the development of hypotension and renal failure in canine babesiosis. A previous study has shown that the severity and outcomes of babesiosis in mice experimentally infected with human babesial strains of B. microti and Babesia duncani depend on the host's immune response and that increased production of TNF- $\alpha$ 
plays an important role in the pathogenesis of the disease (Hemmer et al. 2000). The results of this work allow us to suppose that this cytokine may also have an influence on the severity of babesiosis in dogs. Further work examining the influence of TNF- $\alpha$ on other complications observed in canine babesiosis are needed to understand the role of this cytokine in the pathogenesis of this disease.

Open Access This article is distributed under the terms of the Creative Commons Attribution License which permits any use, distribution, and reproduction in any medium, provided the original author(s) and the source are credited.

\section{References}

Adaszek Ł, Winiarczyk S (2011) In vitro cultivation of Babesia canis canis parasites isolated from dogs in Poland. Parasitol Res 108: 1303-1307. doi:10.1007/s00436-010-2181-7

Adaszek Ł, Górna M, Winiarczyk S (2012) Electrolyte level and blood $\mathrm{pH}$ in dogs infected by various $18 \mathrm{~S}$ RNA strains of Babaesia canis canis on the early stage of babesiosis. Berl Munch Tierarztl Wochenschr 125:45-51. doi:10.2376/0005-9366-125-45

Buranakarl C, Ankanaporn K, Thammacharoen S, Trisiriroj M, Maleeratmongkol T, Thongchai P, Panasjaroen S (2007) Relationships between degree of azotaemia and blood pressure, urinary protein:creatinine ratio and fractional excretion of electrolytes in dogs with renal azotaemia. Vet Res Commun 31:245-257. doi:10.1007/s11259-006-3413-2

Chauvin A, Moreau E, Bonnet S, Plantard O, Malandrin L (2009) Babesia and its hosts: adaptation to long-lasting interactions as a way to achieve efficient transmission. Vet Res 40:37. doi:10.1051/vetres/2009020

Da Silva AS, Martins DB, Soares JF, França RT (2013) Canine rangeliosis: the need for differential diagnosis. Parasitol Res 112: 1329-1332. doi:10.1007/s00436-012-3160-y

Hamel D, Silaghi C, Lescai D, Pfister K (2012) Epidemiological aspects on vector-borne infections in stray and pet dogs from Romania and Hungary with focus on Babesia spp. Parasitol Res 110:1537-1545. doi:10.1007/s00436-011-2659-y

Hemmer RM, Ferrick DA, Conrad PA (2000) Up-regulation of tumor necrosis factor-alpha and interferon-gamma expression in the spleen and lungs of mice infected with the human Babesia isolate WA1. Parasitol Res 86:121-128. doi:10.1007/s004360050021

Irwin PJ, Hutchinson GW (1991) Clinical and pathological findings of Babesia infection in dogs. Aust Vet J 68:204-209. doi:10.1111/j. 1751-0813.1991.tb03194.x

Jacobson LS, Lobetti RG, Becker P, Reyers F, Vaughan-Scott T (2002) Nitric oxide metabolites in naturally occurring canine babesiosis. Vet Parasitol 104:27-41. doi:10.1016/S0304-4017(01)00606-9

Kontaș T, Salmanoğlu B (2006) Tumour necrosis factor- $\alpha$, adenosine deaminase and nitric oxide levels in cattle babesiosis before and after treatment. Bull Vet Inst Pulawy 50:485-487
Krause PJ, Daily J, Telford SR, Vannier E, Lantos P, Spielman A (2007) Shared features in the pathobiology of babesiosis and malaria. Trends Parasitol 23:605-610. doi:10.1016/j.pt.2007.09.005

Lefebvre HP (2011) Renal function testing. In: Bartges J, Polzin DJ (eds) Nephrology and urology of small animals, 1st edn. Wiley, Ames, pp 91-96

Lobetti RG, Jacobson LS (2001) Renal involvement in dogs with babesiosis. J S Afr Vet Assoc 72:23-28. doi:10.4102/jsava.v72i1.604

Máthé A, Dobos-Kovács M, Vörös K (2007) Histological and ultrastructural studies of renal lesions in Babesia canis infected dogs treated with imidocarb. Acta Vet Hung 55:511-523. doi:10.1556/AVet.55. 2007.4.10

Matijatko V, Kiš I, Torti M, Brkljačić M, Kučer N, Rafaj RB, Grden D, Živičnjak T, Mrljak V (2009) Septic shock in canine babesiosis. Vet Parasitol 162:263-270. doi:10.1016/j.vetpar.2009.03.011

Matijatko V, Torti M, Schetters TP (2012) Canine babesiosis in Europe: how many diseases? Trends Parasitol 28:99-105. doi:10.1016/j.pt. 2011.11.003

Paim FC, Da Silva AS, Paim CB, França RT, Costa MM, Duarte MM, Sangoi MB, Moresco RN, Monteiro SG, Lopes ST (2013) Increased cytokine and nitric oxide levels in serum of dogs experimentally infected with Rangelia vitalii. Korean J Parasitol 51:133-137. doi: 10.3347/kjp.2013.51.1.133

Schoeman JP, Rees P, Herrtage ME (2007) Endocrine predictors of mortality in canine babesiosis caused by Babesia canis rossi. Vet Parasitol 148:75-82. doi:10.1016/j.vetpar.2007.06.010

Shaio MF, Lin PR (1998) A case study of cytokine profiles in acute human babesiosis. Am J Trop Med Hyg 58:335-337

Stockham SL, Scott MA (2008) Fundamentals of veterinary clinical pathology, 2nd edn. Blackwell, Ames

Tracey KJ, Lowry SF, Fahey TJ, Albert JD, Fong Y, Hesse D, Beutler B, Manogue KR, Calvano S, Wei H, Cerami A, Shires GT (1987) Cachectin-tumor necrosis factor induces lethal shock and stress hormone responses in the dog. Surg Gynecol Obstet 164:415-422

Waldrop JE (2008) Urinary electrolytes, solutes, and osmolality. Vet Clin N Am Small Anim Pract 38:503-512. doi:10.1016/j.cvsm.2008.01. 011

Watson ADJ (1998) Urine specific gravity in practice. Aust Vet J 76:392398. doi:10.1111/j.1751-0813.1998.tb12384.x

Wozniak EJ, Barr BC, Thomford JW, Yamane I, McDonough SP, Moore PF, Naydan D, Robinson TW, Conrad PA (1997) Clinical, anatomic and immunopathologic characterization of Babesia gibsoni infection in the domestic dog (Canis familiaris). J Parasitol 83:692-699. doi: $10.2307 / 3284248$

Zygner W, Gójska-Zygner O, Wędrychowicz H (2012a) Strong monovalent electrolyte imbalances in serum of dogs infected with Babesia canis. Ticks Tick Borne Dis 3:107-113. doi:10.1016/j.ttbdis.2012. 02.002

Zygner W, Gójska-Zygner O, Wędrychowicz H (2012b) Changes in the SUSPPUP ratio and fractional excretion of strong monovalent electrolytes in hospitalized dogs with canine babesiosis. Pol J Vet Sci 15: 791-792. doi:10.2478/v10181-012-0119-y

Zygner W, Gójska-Zygner O, Wesołowska A, Wędrychowicz H (2013) Urinary creatinine to serum creatinine ratio and renal failure index in dogs infected with Babesia canis. Acta Parasitol 58:297-303. doi: 10.2478/s11686-013-0145-7 